\title{
Message Production Process in Stand Up Comedy: Ethnographic Study in Stand Up Community Indo Surabaya
}

\author{
Dea Rufaidah \\ Communication Department, Faculty of Social and Political Sciences, Universitas Airlangga \\ Jalan Dharmawangsa Dalam 4-6, Indonesia \\ Email: rufaidah.dea@gmail.com
}

\begin{abstract}
A B S T R A C T
The process of producing messages in stand-up comedy is an important issue but is rarely discussed by the academic community. Public often don't realize that the message in stand-up comedy is basically requires a long and complicated preparation process. All messages conveyed in stand-up comedy were actually prepared in meticulous and structured way, especially when deal in sensitive themes such as gender issues, racial discrimination, and socio-economic class issue. The informants in this study are comics, members of the StandUp Indo Surabaya community, individuals who represent various issues in stand-up comedy content that are often discussed. This research shows that the Stand-Up Indo Surabaya community carries out the cultural practice of stand-up comedy or stand-up comedy culture in accordance with the vision of the community and has a peculiarity in the process of producing comedy material collectively. It showed by carrying out routine activities such as knowledge sharing, comedy buddy, open-mic - both conventionally and online through social media Instagram (@standupindo_sby).
\end{abstract}

Keywords: Stand-up comedy, humorous messages, comedy, stand up indo Surabaya.

A B S T R A C T

Proses produksi pesan dalam stand up comedy merupakan isu krusial yang masih jarang dibahas dalam riset akademik. Publik seringkali tidak menyadari bahwa pesan dalam stand up comedy pada dasarnya membutuhkan proses persiapan yang panjang dan rumit. Lebih jauh lagi para proses produksi ini semua pesan yang disampaikan dalam stand up comedy sejatinya disiapkan, termasuk dalam tema-tema besar seperti isu gender, diskriminasi rasial, dan juga kelas. Informan dalam penelitian ini merupakan para comedians, anggota komunitas Stand Up Indo Surabaya, individu yang mewakili berbagai macam isu pada konten stand up comedy yang sering dibicarakan. Penelitian ini menunjukkan bahwa komunitas Stand Up Indo Surabaya menjalankan praktik budaya stand up comedy atau stand up comedy culture sesuai dengan visi komunitas yang dipunya dan memiliki kekhasan dalam proses produksi materi komedi secara kolektif. Hal tersebut diwujudkan dengan pelaksanaan kegiatan secara rutin seperti sharing ilmu, comedy buddy, open mic_-baik secara konvensional maupun online melalui sosial media Instagram (@standupindo_sby).

Kata kunci: Stand up comedy, pesan humor, komedi, stand up indo Surabaya.

\section{A. INTRODUCTION}

The development of the world of comedy entertainment is growing rapidly due to the many demands for live-entertainment in the form of competitive creativity, the type of audience and the variety of art workers, as well as problems in the life of the entertainment market (Pragiwaksono, 2012). In the world of entertainment itself comedy has nothing to do with humor. According to Freud, humor is a form of communication, overcoming individual emotions and is one of the various defense mechanisms that enable a person to face difficult situations without being affected by unpleasant emotions (Martin \& Lefcourt, 2006). 
Comedy is a necessity in today's entertainment world. The entertainment industry needs art workers who are commonly called comedians, who able to provide a touch of humor entertainment so that the audience will be entertained and make the atmosphere more relaxed. Often humor is found in a place close to human life. Starting from workplaces, restaurants, to suburban stalls. Humor is an inevitable topic and discussion. Humor can also be used in the approach to the business field or the approach to partners (Stebbins, 1990).

Comedy art workers in Indonesia are accustomed to presenting comedy in the form of groups, such as ludruk or lenong bocah, sketches, and set shows on television programs. However the world of comedy is experiencing a development which is marked by the presence of the concept of comedy solo or the appearance of one person. This is known as Stand Up Comedy. Initially in the 1950s, monologue comedy had flourished in the Indonesian entertainment scene. However, the term Stand Up Comedy only emerged and was adopted as a television program concept in 2004.

Based on previous research (Pragiwaksono, 2012), the mention of the term "Stand Up Comedy" is often confused with the meaning of being funny while standing up. The meaning of "Stand Up" as meant in the art of stand up comedy is where individuals who come to the stage full with anxiety and defend their personal opinions. Comedians is the term for host in Stand Up Comedy. They bring material that comes from personal issues and concerns which considered relevant to society. Sometimes this comedian will dressed humorously in front of the audience to incite laughter. Comedians was said to have succeeded in bringing material if the laughter reached the predetermined calculations. The more boisterous laughter you comedian get, the material presented is relevant and entertaining (Papana, 2012) Stand Up Comedy is a place for someone to express themselves and through comedy someone wants their opinion to be heard. Furthermore, Stand Up Comedy is an art performance performed individually in front of the audience in monologue. Papana said that every comedian brought jokes on stage to provoke laughter from the audience (Papana, 2012).

Based on the researchers' preliminary observations, Open Mic in Stand Up Comedy is a live performance which act as a medium for everyone who interested in performing. Usually Open Mic is an opportunity for Comedians to increase their popularity. The community often makes open mic a mandatory event every week. In addition to increasing popularity, open mic proved to attract larger audience if it is held regularly and planned carefully. Over the time many people are interested in coming and eventually become regular spectators.

Adde Malmberg suggests eight characteristics to explain stand-up comedy, namely : one has to be funny, one has to be alone, one has to stand up, one has to talk directly to the audience, one has to be oneself, one should not be dependent upon the context, one shall not use props, and one shall not use a written script (Sjöbohm, 2008). Of the eight characteristics, it can be used as a reference to distinguish stand-up comedy from other forms of comedy performances. Stand up comedy prioritizes verbal messages in its performances. As well as doing a speech, a comic must first draft the text for his humorous 'speech'. Attardo described stand up comedy as "a highly artificial, scripted genre" (Schwarz, 2010). The script is an important part of a comic. Choosing a 
theme, the humor contained in the various stories is prepared in advance. A comic does not only prepare a script, but must test the script in an open mic event. Comedians always emphasizes laughter as something important to achieve in her appearance. So that the process of making comedy material can be said to be not easy and must be carefully thought out with the correct technique as well. Based on this description, the comics have to go through various processes starting from preparation, from writing material to rehearsal, before being presented to the audience on stage.

Stand Up Comedy Indonesia is a stand up competition followed by numerous aspiring comedians throughout Indonesia, which is held by Kompas TV. This competition is the first in Indonesia so that it is considered as a measure of high achievement for comics. Support from private television encouraged more experienced comedians to establish a Stand Up Comedy Indonesia community with the hope of attract more attention and good reception within the community. The Indonesian Stand Up Comedy Community or Stand Up Indo for short, was founded by Pandji Pragiwaksono, Raditya Dika, Ernest Prakasa and Isman HS on July 13, 2011. The good reception from the community has also helped Stand Up Comedy entertainment more accesible and garner more attention in Indonesia.

Community is a group of people who gather because of the similar values and interests. Individuals who are members of the human community can have similar resources, intentions, beliefs, references, needs, risks and conditions. Based on this description, Stand Up Indo can be classified as community because it includes members who have the same interests and values regarding the art of stand up comedy. The most important factor in forming a community is the similarity of the Frame of Reference (FOR) and the Frame of Experience (FOE). The community will be a group of individuals who have the same scope, which is a collective identifier for the community itself.

Surabaya has a Stand Up Comedy community which is known as the largest community in East Java. The number of members is also the largest among other communities. Thanks to the persistence of its members, Stand Up Indo Surabaya has produced many famous comedians such as Dodit Mulyanto, Topenk, Arif and Tretan Muslim. The contribution of the Stand Up Indo Surabaya community in the development of stand up comedy in East Java is quite significant. This certainly makes the Stand Up Indo Surabaya community interesting to examine how the Stand Up Indo Surabaya community then becomes unique and different from other stand-up communities in Indonesia.

Apart from carrying out activities offline, the Stand Up Indo Surabaya community also carries out activities through social media Instagram, thus making this community a modern community or it can be called a virtual community. A virtual community is a virtual space in which all information needs can be provided in an easily understood language. Furthermore, a virtual community is a community that is expected to be able to transcend physical boundaries that are far from human.

The dynamic movement of information as well as the flow of knowledge from various lines allows individuals who are members of a community to create innovative content. In making it 
also involves a collaborative process with the existing facilities. The Indo Surabaya Stand Up Community consists of individuals who have the same interest in the art of stand up comedy entertainment, who want more structured, strong, and growing community. Faraj and Johnson suggest that group communication patterns in virtual communities focus on reciprocal communication which is expected to generate preferential attachments and direct \& indirect reciprocity.

In the social community, existing information flows automatically and does not guarantee an invisible reciprocal process. It is very symbolic and in fact can strengthen the sense of solidarity and belonging among the members within it. Indirect reciprocity is often encountered and occurs in online communities, which causes a gap in time and space. In this context, social media as new media has the use of removing the boundaries of space and time so that in the end the context of communication can run in harmony at the same time. Strong attachment with community is the most important element which is the main asset for individuals in the community to be recognized by other members. In fact, individuals who have recently joined the community often get closer to the most active members. This is done solely because it can dig up more information and in the end can build a good relationship with that individual.

In addition to punch lines, comics also often use one-liner techniques in delivering their Stand Up Comedy material. One-liner stand-up is a type of Stand Up Comedy in which a comic presents a short joke material, which can consist of short sentences that are sometimes discontinuous. The one-liner strictly adheres to the structure in the construction of a joke, namely the presence of the set-up and the punch line. This refers to the notion conveyed by Notaslimboy where the one-liner is a short joke which only consists of a few sentences, the initial sentence; in the form of a set-up and the final sentence in the form of a punch line. This is also reinforced by (Prakasa, 2012) which mentions a one-liner as a joke which only consists of two to three short sentences. One-liner as a type of Stand Up Comedy jokes delivered by comedian in the form of materials consisting of two to three sentences and quickly generate laughter from the audience.

Most of the jokes in Stand Up Comedy is made up of two structures that can be classified into a set-up section and a punch line section. According to Dean, set-up is a part that aims to create expectations in the minds of the audience (Dean, 2012). The punch line technique is the most important part in making Stand Up Comedy material. Punch lines can be words or actions that are used to surprise the audience (Dean, 2012). The punch line or also known as the punch is the second part of the joke structure that makes the audience laugh (Papana, 2012). Notaslimboy states that the punch line is part of a joke that provides a surprise at the end that does not match the audience's initial assumptions. The punch line section can be supported with three aids to make it even stronger and make it more likely to generate greater laughter. The first aid is an actout, which is a body movement or facial expression performed by comics in their performance to bring or strengthen a joke (Papana, 2012). The second help is with the tagline or it can also be called a double punch. The tagline is a short sentence that is said by comedians after saying the punch line (Papana, 2012). This tagline is done to add greater laughter and usually will bring up the third assumption and even more and make the audience less likely to guess the end of a joke. 
The last help is to make a callback. This assistance is a little bit difficult to do. Callback is a joke that has the same punch line as the punch line in the previous joke (Papana, 2012) and is usually presented in a much different context but still has continuity in both words, phrases or sentences.

In addition to punch lines, comics also often use one-liner techniques in delivering their Stand Up Comedy material. One-liner stand-up is a type of Stand Up Comedy in which a comic presents a short joke material, which can consist of short sentences that are sometimes discontinuous. The one-liner strictly adheres to the structure in the construction of a joke, namely the presence of the set-up and the punch line. This refers to the notion conveyed by Notaslimboy where the one-liner is a short joke which only consists of a few sentences, the initial sentence; in the form of a set-up and the final sentence in the form of a punch line. This is also reinforced by (Prakasa, 2012) which mentions a one-liner as a joke which only consists of two to three short sentences. So, one-liner as a type of Stand Up Comedy delivered by comics is in the form of materials consisting of two to three sentences and quickly generate laughter from the audience.

Truzzi explains that a businessman is a mediator for comedian (Stebbins, 1990). They have a role to promote the abilities and talents they have, organize their performances and performances in such a way. In essence, they help ensure a livelihood for the comics as professional entertainers. Less experienced professionals typically rely on one agency to arrange most of their work as live entertainers. (Stebbins, 1990).

In his book, entitled The Laugh Makers: Stand Up Comedy as Art, Business and Life-Style, (Stebbins, 1990) provides an example of how professional comics in Canada rely on one agency to manage most of their work in stand-up comedy shows. The examples including Funny Business Production (Yuk's), Punchlines in the city of Vancouver, and also The Comedy Next in the city of Montreal. The agency is like a group that has several managers and is affiliated with a general entertainment agency that manages a smaller number of comedians. Stand-up comedy in the west is more commercial and act as business entity in nature.

'Business Opportunities in the Hit Genre of Stand-up Comedy' states that many people consider the decision to be a comedian as a naive act. However, he added that in reality the stand-up comedy entertainment sector is getting a strong demand and is considered comedian to have promising future. The ease and availability of pop-up comedic spaces should lead to better exposure. For example places such as cafes, pubs, galleries can get more attention by instilling the art of comedy as an experience that enriches part of the services offered. Departing from this argument, the popularity of stand up comedy as a business will be more and more widespread.

Comedy club is the heart of stand-up comedy, while the comedians are its soul. It is within the comedy club that the majority of respondents in this study started their careers. In his research Stebbins respondents who were comedians from Canada started their careers through comedy clubs. Comedy clubs are a place where everyone can enjoy comedy shows, be more intimate, while selling food and drinks. In the United States, quite a number of comedy clubs are created by comedians and work with promoters to run comedy shows on a regular and commercial basis. There they have the intimacy they need to produce a good comedic message (Stebbins, 1990). 
Until 2011 comedy club never really popular and widespread in Indonesia because the art of stand-up comedy was originally present as an art that was cultivated communally. Starting with the establishment of the Stand Up Indo community in 2011, stand up comedy communities have emerged and developed in various regions and cities. The purpose of these stand-up communities is to ensure all members can progress and grow together, enriching the comedy entertainment world in Indonesia.

According to one prominent comedian from Bandung, Isman HS, regional stand up comedy communities started their activities by creating social media twitter and Instagram, then holding regular events in the form of open mic. The term open mic is the term for an open stage that is held for anyone to perform on a stand-up. Usually held in cafes, restaurants, equipped with a supporting stage set. Open mic is also an activity for comedian to gather and mingle with each other.

The progressive development of popular culture has changed public acceptance of cultural products, including comedy. The sensitivity regarding political and social issues discussed in entertainment product has also changed especially in Indonesia. However, when these issues were covered within stand-up comedy, people felt stand-up comedy provides more to complaining and providing solutions, albeit wrapped with jokes. Bhaskara (2020) in Dharma (2020) argues that "... art should comfort the disturbed and disturb the comfortable." That is, comedy and other forms of art must be "disturbing" in order to create public sensitivity regarding the issues raised. Besides having a position in political openness stand-up comedy also acts as an expression of humor.

Minorities is one of the sensitive issue with actively avoided in other entertainment product, from movie to music. The existence of different identities is the beginning of the emergence of SARA problems in Indonesia, marked by the presence of strong stereotypes and discrimination among minorities. The birth of the art of stand-up comedy in Indonesia has eventually become a medium for minorities to be more open in communicating taboo matters. One important example is issue of racism in Indonesia, which is often experienced and encountered by Chinese ethnic. With stand-up comedy, such sensitive issues are packaged with a perspective and delivery that can be accepted more lightly. After reformation, the Indonesian government finally recognized the existence of ethnic Chinese again by protecting them through Law no. 12 of 2006 concerning Citizenship of the Republic of Indonesia. The Chinese ethnic community then began to show their existence in various aspects of life such as politics, social, culture, and also in the entertainment sector. The world of stand-up comedy is no exception. The great opportunity for comedy or humor as a counter narrative of racism, as well as an effective means of public education, seems to be evaporating. As a popular culture product, it provides a lens to understand what racial hegemony is. Comedy, which is critical in nature, can also create critical thinking for each individual in his efforts to overcome social problems, such as racism.

At the social structural level all societies make distinctions based on gender. Gender greatly affects the access to power, status, and resources. Gender equality is legally guaranteed. Over time there have been various debates to regress and eliminate some inappropriate progress, many 
have been proclaimed to protect women. In that context, comedy can play an interesting role that contributes to feminism and diversity of understanding. It is a fact that speeches, comedy sketches, especially stand-up comedies are very entertaining. Everything has the consequence that any form of story that is communicated later with comedy will be more easily accepted by the audience. This is emphasized in a recent study on comedy from the Center for Media \& Social Impact (CMSI) at the American University's School of Communication (2017), which has produced a report entitled 'The Laughter Effect: The [Serious] Role of Comedy in Social Change'. The report concludes that all kinds of humorous formats can offer avenues to dissect and reveal various social problems, including gender issues.

\section{B. METHOD}

This research uses a qualitative approach. In this study, researchers conducted participant-observation, or directly observed research subjects. This research focuses on how the stand up comedy culture is implemented by the Stand Up Indo Surabaya community as well as how the comics process produces messages in stand up comedy. Both will be examined from the series of activities carried out by the Stand Up Indo Surabaya community, which are related to stand up comedy directly or through social media.

The data collection technique used in this study was to conduct in-depth interviews and also observation to five members who are members of the Stand Up Indo Surabaya community as comedians, namely Dono Pradana, Yudhit Ciphardian, Idhamsyah, Steven Wongso, and Ichan Wahyuti. Researchers also interviewed informants who were met accidentally, in which the individual was actively involved in the activities of the Stand Up Indo Surabaya community both in person and through social media.

\section{RESULTS AND DISCUSSION}

During the research process, the researcher saw that the Stand Up Indo Surabaya community had a unique way of making stand up comedy material in groups. This can be seen from a series of events such as comedy buddy and knowledge sharing. It is very important for comedians to pay close attention to the comedy material that is made. Helitzer (2005) states that some comedians feel that the ability to write comedy material is passed down from generation to generation, not learned, and may be shaped by factors such as the ethnic characteristics of comics, childhood experiences, and perceived anxiety. However, in his book entitled "Comedy Writing Secrets", he adds "... anyone can learn to write humor. Although some individuals are naturally funnier than others, just as some individuals are more athletic or more musically gifted, humor writing can be taught and humor-writing skills can be acquired. " Anyone can write humor or comedy material. The skills for this can be honed and acquired by studying. Humor and comedy material is not a mystery, just like magic tricks on stage. So that it is possible for anyone to dissect and study it. 
Comedy buddy activities and knowledge sharing are activities in which in groups where comedians compile material together and help each other and teach each other writing comedy material. In each Combud (comedy buddy) session, each Comedians is free to choose anyone to consult in compiling the material. Idhamsyah admitted that combud is an important part in the process of making comedy material for comics. Regarding this, Idhamsyah said: "Initially my material still came from myself, from an uneasy restlessness I've experienced. Then in the end it developed into an opinion, the result of observation and I shared it with other comedians as well. If you find the funny thing, it's also from seeing your friends' performances, including combud, "(personal communication, 5 June 2020).

During the research period, I attended an open mic event and participated in a series of activities from the Stand Up Indo Surabaya community. I also observed how they hone their comedy skills to be presented on stage to the audience. Comedians adopt a stage persona and use narrative tools that are standard in comedy - namely incongruity, exaggregration, mockery, reversal, superiority, and relief. Researchers also found that the material made by the comic strips originated from the thoughts, the restlessness and anxiety they felt, which was poured out and brought onto the stag, by paying attention to the atmosphere of the place and the condition of the hearts of the audience. However, these standards are not used as a reference that must be done in the manufacture of materials for comedians. During the research, I found that the knowledge taught in the Stand Up Indo Surabaya community is truly varied. They do not have a particular school of thought in comedy. There are so many syntheses, because the most important thing is the knowledge itself.

Regarding the material written, comedians must understand which material is funny and which is not. Because every material has the possibility to offend anyone on the audience. However, stand-up comedy is not about who offends and who is offended but how can a comic be responsible for his work. Comedians must understand the context and power relations in the material. The rest depends on the audience. Comedians also needs an audience. The response from the audience is an important thing to pay attention to in seeing the limits of the material being delivered whether it is sensitive or not. The key is in the object that is used as material, comedians's personal sensitivity, and the acceptance of the audience.

Steven is one of the comics who often presents comedy material that contains social criticism about ethnic Chinese discrimination, according to his background. In the process of writing the material, Steven never encountered any significant difficulties. Steven casually explained: "In looking for anxiety, I never find it difficult because yes I'm Chinese. Many things to be worried. I am the strongest discussing material about race. So far, many have received bad stigma, from there I process it into stand-up material, (personal communication, June 2, 2020). $\mathrm{He}$ admits that during his career in the stand-up world in the past 2 years, jokes about the "Chinese" side of him have always succeeded in breaking the laughter of the audience.

In the research process, the researcher saw that the pandemic did not limit the comic in the Stand Up Indo Surabaya community, or anyone who could still be funny in standing up. There are so many media that can be used to hone one's comedy skills, not only limited to open 
mic events. This can be done by recording yourself, writing stories that contain a comedy side, and much more. In addition, the appearance of the comics on stage both offline and online is not much different. Stay based on the material you have and your ability to deliver to the audience. The comics in the Stand Up Indo Surabaya community can also overcome crises that occur on stage with various techniques that have been taught in the comedy buddy session as well as knowledge sharing. One method that is often applied is riffing. Riffing uses Javanese as a punch line and a little sarcasm is the hallmark of the comics of the Stand Up Indo Surabaya community.

Apart from coming from self-restlessness, comedian material also depends on external phenomena and their environment in order to develop and continue to exist. Basically, stand up comedy is a kind of comedy that is quite simple because it doesn't require anything but a few properties to support the comics' appearance. According to (Glick, 2007) "... a lone comedian stands on a stage with a microphone and talks to an audience that has paid to be present," in other words, Comedians just stands on stage and speaks using a microphone.

During the COVID-19 pandemic, researchers found that the Stand Up Indo Surabaya community continued to carry out activities as usual using social media. Starting with creating content on Instagram (@standupindo_sby), holding an online open mic, all of this is done to keep the audience entertained. The Stand Up Indo Surabaya Community carries out these activities regularly for one full week. Some comics also participated in online stand up competitions held by external parties.

The researcher found that the stand up comedy community in Indo Surabaya has the characteristic of using Javanese language in its stand up comedy message. This is done because Javanese is the language of everyday life in Surabaya. They also feel that by using Javanese language, the audience will understand better the context of the material presented. Apart from using Javanese in its stand-up comedy message, the Stand Up Indo Surabaya community comedy also has a distinctive Suroboyoan punch line. The punch line is synonymous with the Surabaya dialect, as well as harsh words in everyday language.

The adjustment of the use of harsh words in stand up comedy messages in the Stand Up Indo Surabaya community is quite unique. Many comics use the word "jancok" or "choke" at the end of the punch line to add an emotional impression to stand up. Due to the unrest and the story that is told must be wrapped in honesty, annoyance is no exception. The researcher found that there were two categories of placing the word misuh in the comic punch line of the Stand Up Indo Surabaya community. First, the placement of the rant on the front, and also the placement at the end of the punch line. According to (Shatz \& Helitzer, 2005) ".. the emotion is usually anger or hostility driven by the stupidity, absurdity, or weirdness of the premise." In other words, emotion is needed by the comic as reinforcement of the material presented. The clearer the emotions shown, the more understanding the audience will be. Lastly, there is explicitness or clarity. Where the premise of an effective punch line is one that is specific and easily understood by others. Comedians in the Stand Up Indo Surabaya community is characterized by an emotional punch line. While there is a difference between being rude and funny, there are times when those words should be used in being funny. Every word in humor is a missile designed 
with care. Calculated in such a way as to penetrate the audience's mind and create a very specific impact; laughter.

Stand Up Indo Surabaya is considered to be a community that has initiated the development of the stand up comedy community in East Java. Apart from being the first community to be formed after Jakarta or the central part, Stand Up Indo Surabaya has also become a center for stand-up communities in the East Java region, both in making events and the community managerial system. Based on the explanation above as a community, Stand Up Indo Surabaya was built and run very cohesive. This is illustrated by how they support each other to progress together, especially in terms of each other's comedy careers. Furthermore, cohesiveness is a dynamic process that is influenced by the tendency of group attachment and unity to stay together and unite in pursuing the fulfillment of common goals. It was manifested by how the Stand Up Indo Surabaya community made a new comedy regeneration, and also the birth of a local comedy club to continue to grow and expand their career reach in the world of Indonesian comedy.

As a stand up comedy community, Stand Up Indo Surabaya has contributed many names to the comedy entertainment stage on the national scene. What is unique about the Stand Up Indo Surabaya community is how they regenerate. Every year, there is always an annual stand up comedy Indonesia (SUCI) competition at KOMPAS TV, as well as a stand-up comedy academy (SUCA) in Indosiar. The researcher found that there are always several comic stand up communities in Indo Surabaya who take part in the competition until the final round, and some have won. Due to their community-based, community-based, mutual cooperation, Stand Up Indo Surabaya comics often give full support to anyone who has succeeded in penetrating the national stand-up competition stage. In addition to the support given when a comic manages to get to the stage of the national competition, the Stand Up Indo Surabaya community also often provides jobs for one another. Share jobs with each other when you get a call to fill in events such as seminars, product launches, and others.

After being successful in the national comedy scene in Indonesia, many comics from the Stand Up Indo Surabaya community have penetrated into the film and other entertainment industries. In addition, there are those who try to make their own comedy club to make business matters easier in their comedy career. As did Dono Pradana. In 2016, Dono and five other comics friends founded the first Comedy Club in Surabaya, namely Comedy Sunday. With Comedy Sunday, Dono wants to present a stand up show that is more than just an open mic event. The program titled "NYCT" or nyocot (talkative) by Comedy Sunday emphasizes an exclusive and conceptual impression. The café which is the venue for the "NYCT" event is considered luxurious and is usually dominated by the upper middle class. Because Dono has become part of MLI, MLI has also acquired the Comedy Sunday business. It cannot be denied that this step turned out to have a very significant impact on Comedy Sunday's progress as a Comedy Club in Surabaya. In the end, Comedy Sunday succeeded in becoming a new forum for Surabaya comics to have a more focused career. However, the biggest concern is that the talents of the Stand Up Indo Surabaya community will be replaced because of the comedy club, not 
from the community. Meanwhile, historically, it was the community that built the comedy entertainment scene in Surabaya before the comedy club as it is today. Not only in Surabaya, but also in Indonesia.

\section{CONCLUSION}

The Stand Up Indo Surabaya Community carries out the cultural practice of stand up comedy or stand up comedy culture in accordance with the vision of the community they have. This is realized through routine activities such as sharing knowledge, comedy buddy, open mic both conventionally and online through social media Instagram (@standupindo_sby), mini shows, as well as the community's annual Stand Up Nite (SUN) show. The production process of the comedy material message for the comics individually depends on the research and planning process of each. However, the stages that are passed tend to be the same starting from the simplest material writing process, namely arranging the set up and the punch line.

The comics of the Stand Up Indo Surabaya community have a distinctive feature of using the Javanese language in their stand up comedy messages. Apart from using Javanese in its stand-up comedy message, the Stand Up Indo Surabaya community comedy also has a distinctive Suroboyoan punch line. The punch line is synonymous with the Surabaya dialect, as well as harsh words in everyday language. This is done because Javanese is the language of everyday life in Surabaya. Making comedy material in groups because it is community-based, comics regularly carry out comedy buddy (combud) activities and knowledge sharing. Where there is always one senior comic who provides direction in each session. The comics then tested their mature material on stage during the open mic.

There is no particular school in comedy that is used as a role model in the Stand Up Indo Surabaya community. The science of stand up comedy being taught is truly hybrid. There are a lot of syntheses and the most important thing is not about who tells, but what is being taught. Every comedians has the right to notify and be notified. However, at the initial stage, basic things are always taught, such as making a set up and punch line, how to write solid material and maximum delivery.

Sensitivity is very important for comics to have in stand-up comedy. In including values that are social criticism in comedy material, it depends on the conscience of each comics. There is no limit to the topic of a joke. Every comedy material must have the possibility of offense. But stand up comedy is not about who is offended and who is offending. It's how the comics are responsible for the material presented. The comics in the Stand Up Indo Surabaya community understand the context and power relations in their comedy material. They also match each jokes to the audience. The response from the audience is an important thing to pay attention to in seeing the limits of the material being delivered whether it is sensitive or not. The key is in the object that is used as material, comedians's personal sensitivity, and the acceptance of the audience.

Stand Up Indo Surabaya Community has succeeded in creating a stand up comedy scene 
and ecosystem that is almost similar to stand up shows in the west where it is used as a mecca or benchmark in holding every event. Usually the Stand Up Indo Surabaya community invites comics outside the city if there is a stand up show to establish friendship, then gives them the opportunity to share knowledge with fellow community members (forming a scene indirectly). If other communities are invited to come to their events, they will definitely come and help promote. Researchers also see that the audience is also close to community members through social media exchanges after the event is over, so that an ideal stand-up comedy ecosystem will be formed.

During the transition period before and after the pandemic, the Stand Up Indo Surabaya community was able to maintain the implementation of the stand up comedy culture by using the Instagram social media they had (@standupindo_sby). They are often active in creating content and open mic events, sharing knowledge online so that they can entertain followers and viewers. Researchers see the significance of Instagram social media in making it easier for the Stand Up Indo Surabaya community to continue working.

\section{BIBLIOGRAPHY}

Dean, G. (2012). Step by Step to Standup Comedy. Bukune.

Martin, R. A., \& Lefcourt, H. M. (2006). Sense of humor as a moderator of the relation between stressors and moods. Journal of Personality and Social Psychology, 45(6), 1313-1324. https://doi.org/10.1037/0022-3514.45.6.1313

Papana, R. (2012). Kiat Tahap Awal Belajar Stand Up Comedy Indonesia. Mediakita.

Pragiwaksono, P. (2012). Merdeka dalam Bercanda. Bentang.

Prakasa, E. (2012). Dari Merem ke Melek; Catatan Seorang Komedian. KPG (Kepustakaan Populer Gramedia).

Schwarz, J. (2010). Linguistic Aspect of Verbal Humor in Stand Up Comedy. Universitat des Saarlandes.

Shatz, M., \& Helitzer, M. (2005). Comedy Writing Secrets: The Best-Selling Book on How to Think Funny, Write Funny, Act Funny, And Get Paid For It. Writer's Digest Book.

Sjöbohm, J. (2008). Stand-up comedy around the world: Americanisation and the role of globalised media. Konst, Kulture Och Kommunikation Medie-Och Kommunikationsvetenskap, 30. http://dspace.mah.se/handle/2043/6172

Stebbins, R. A. (1990). The Laugh-Makers: Stand-Up Comedy as Art, Business, and Life-Style. McGuill-Queen's University Press Montreal \& Kingston. 